\title{
Probabilistic seismic hazard in terms of intensities for Bulgaria and Romania - updated hazard maps
}

\author{
G. Leydecker ${ }^{*}$, H. Busche ${ }^{*}$, K.-P. Bonjer ${ }^{2}$, T. Schmitt ${ }^{1}$, D. Kaiser ${ }^{1}$, S. Simeonova ${ }^{3}$, D. Solakov ${ }^{3}$, and L. Ardeleanu ${ }^{4}$ \\ ${ }^{1}$ Federal Institute for Geosciences and Natural Resources, Hannover, Germany \\ ${ }^{2}$ Geophysical Institute University of Karlsruhe, Germany \\ ${ }^{3}$ Bulgarian Academy of Sciences, Geophys. Instit., Seismolog. Depart., Sofia, Bulgaria \\ ${ }^{4}$ National Institute for Earth Physics, Bucharest, Romania \\ * formerly at: Federal Institute for Geosciences and Natural Resources, Hannover, Germany
}

Received: 18 July 2008 - Revised: 20 October 2008 - Accepted: 20 October 2008 - Published: 16 December 2008

\begin{abstract}
Since 2007 Bulgaria and Romania are members of the European Union. All member states have to introduce the European earthquake building code EUROCODE 8 (EC 8) in the coming years. Therefore, new seismic hazard maps have to be calculated according to the recommendations in EC 8 . Here the authors present a novel approach to compute such hazard maps. We prefer to use the macroseismic intensity as hazard parameter because of two reasons:

- The irregular azimuthal attenuation pattern of the Vrancea intermediate depth earthquakes can be advantageously taken into account by using detailed macroseismic maps.

- The intensity is directly related to the degree of damage and is the original information in the historical earthquake catalogues.
\end{abstract}

The main base of our probabilistic analysis is the earthquake catalogue for SE-Europe (Shebalin et al., 1998) in combination with national and regional catalogues. Fore- and aftershocks were removed. Seismic source zones inside an area of about $200 \mathrm{~km}$ around Romania and Bulgaria were defined based on seismicity, neotectonics and geological development. For each seismic source the intensity-frequency relation was calculated and a maximum possible earthquake as well as a seismogenic depth was estimated. An appropriate attenuation law was assumed. To cope with the irregular isoseismals of the Vrancea intermediate depth earthquakes, a factor $\Omega$ was included in the macroseismic attenuation law.

Using detailed macroseismic maps of three strong intermediate depth earthquakes, $\Omega$ was calculated for each observation. Strong local variations of $\Omega$ are avoided by averaging

Correspondence to: G. Leydecker (guenter.leydecker@web.de) within grid cells of 0.5 degree in longitude and 0.25 degree in latitude.

The contributions of all seismic sources, the crustal normal depth source zones and the Vrancea intermediate depth zone, were summed up and the annual probability of exceedance was calculated. The contribution of the Vrancea intermediate depth zone to each grid point was computed with the corresponding representative $\Omega$ of this point; a seismogenic depth of $120 \mathrm{~km}$ has been assumed.

Each final seismic hazard map is a combination of two maps, the one for normal depth source zones and the one for the Vrancea intermediate depth zone. This is illustrated for a recurrence period of 475 years. Additional hazard maps were calculated for different recurrence periods.

\section{Introduction}

Romania and Bulgaria are situated in the Carpathian-Balkan Region as a part of the Alpine-Himalayan seismic belt. They are characterized by high seismicity, and are exposed to a high seismic risk. Over the centuries, the two countries experienced strong earthquakes. Because both countries are now members of the European Union, they are committed to introduce the EUROCODE 8 (EC8). For the application of this building code seismic hazard maps with a single hazard parameter such as macroseismic intensity, peak ground acceleration or spectral acceleration, each is possible, have to be calculated. Based on these results, hazard zones with dedicated referenced peak ground accelerations have to be determined in a further process. In this paper we present a special way to compute such hazard maps. We prefer to use here instead of magnitude the macroseismic intensity to calculate hazard maps, because this parameter is the original parameter

Published by Copernicus Publications on behalf of the European Geosciences Union. 


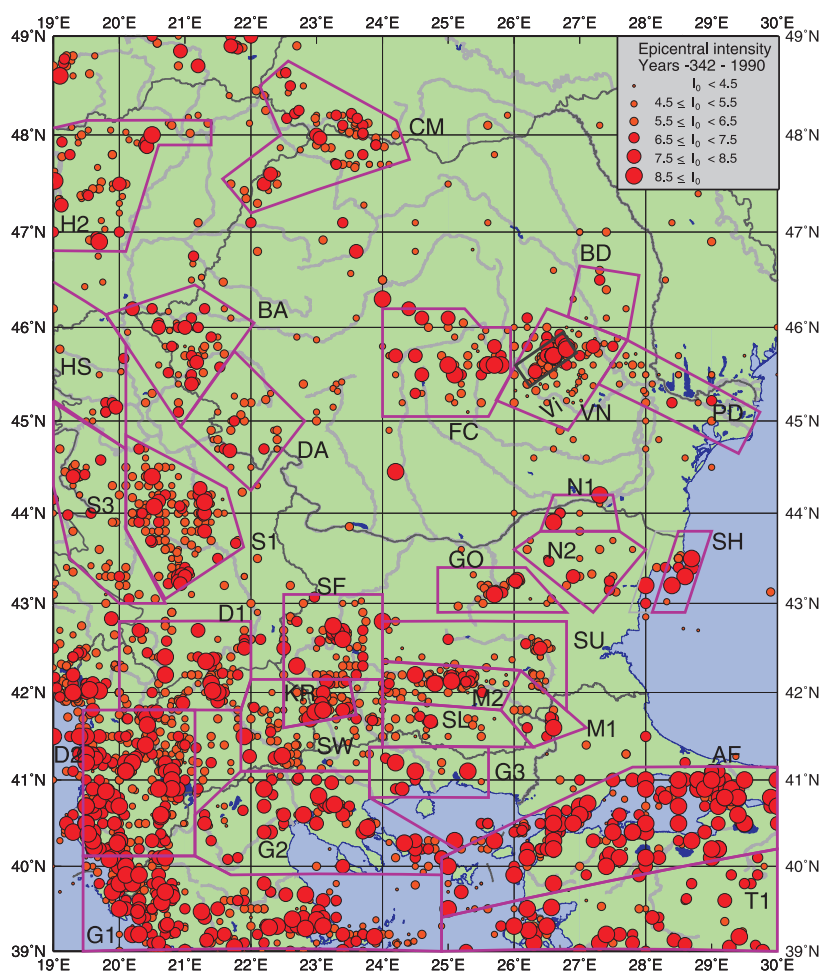

Fig. 1. Earthquake epicenter map ( $I_{0}=$ epicentral intensity) with the seismic source zones. Codes of source zones and their parameters are listed in Table 1.

in historical earthquake catalogues. A great advantage of using intensities is that the very irregular pattern of the attenuation field of the Vrancea intermediate depth earthquakes can be estimated from detailed macroseismic observations. The seismic hazard is computed with EQRISK (McGuire, 1976), based on the probabilistic approach developed by Cornell (1968).

During the last decades, several papers have been published about the seismic hazard in Bulgaria and in Romania. An overview about these approaches is already given in Ardeleanu et al. (2005) for Romania and in Simeonova et al. (2006) for Bulgaria. The presented earthquake hazard maps are an update respectively improvement of the maps in Ardeleanu et al. (2007).

\subsubsection{Earthquake catalogue and seismic source zones}

The main base of our probabilistic analysis is the earthquake catalogue for SE-Europe (Shebalin et al., 1998) in combination with the Romanian catalogues (for references see Oncescu et al., 1999) and some further national and regional catalogues (Christoskov et al., 1979; Grigorova et al., 1979; Solakov and Simeonova, 1993; Papazachos et al., 2000, 2005). From these different catalogues Ardeleanu et al. (2005) and Simeonova et al. (2006) compiled a homogeneous earthquake catalogue.
As a Poisson model for the seismicity is assumed, only independent events should be included in the analyses. The fore- and aftershocks were removed by using a space-time window. In the case of more than one earthquake within 10 days and $50 \mathrm{~km}$ distance only the strongest event is used for the statistics; the others are considered as statistically dependent and rejected from the catalogue. The resulting earthquake catalogue of the considered area consists of nearly 2750 events with epicentral intensities $I_{\text {epic }} \geq 4$.

The completeness of the catalogue was examined using Stepp's (1971) test. Stepp's (1971) analysis provides a method for the analytical determination of time intervals in which a particular intensity class (or magnitude) is likely to be reported completely. The test results imply that it is possible to create homogeneous data samples by determining intervals over which earthquakes in different intensity classes are completely reported.

The spatial pattern of seismicity in an area of about $200 \mathrm{~km}$ around the territory of Romania and Bulgaria is shown in Fig. 1. The figure shows the earthquakes with $I_{\text {epic }} \geq 4$ reported in the time $342 \mathrm{BC}-1990 \mathrm{AD}$, together with the seismic source zones. Each zone is characterized and defined by its own specific seismicity, and geological and tectonic development. From our seismotectonic analysis of the considered area this seems more appropriate than to use specific linear fault structures. It is assumed that an earthquake can occur within a source zone at every point with equal probability. The boundaries of these zones were chosen to reflect the seismicity adequately regarding tectonic units and lithospheric structure. The seismic sources are mostly the same as in Simeonova et al. (2006), and in Ardeleanu et al. (2007), with small differences in Bulgaria (Report GPh.I., 2007) and for Vrancea intermediate depth seismic zone (see below). All earthquakes outside the designed sources are assigned to the "background seismicity".

From the analysis of the depth distribution it was recognized that the earthquakes in all zones occurred in the Earth's crust $(h<60 \mathrm{~km})$, with the exception of the events in the Vrancea (Romania) intermediate depth zone. The seismogenic depth of each zone is defined as the depth of maximum seismic energy release and is given in Table 1 .

The seismicity within the Vrancea (Romania) region consists of two depths domains: normal depth (less than $60 \mathrm{~km}$ ) and intermediate depth $(60-180 \mathrm{~km})$ earthquakes. Due to extreme irregularities of the isoseismals of intermediate depth earthquakes their effects on seismic hazard have to be treated separately. The size of the Vrancea intermediate depth seismic zone is confined to an area of $20 \times 60 \mathrm{~km}^{2}$ (Bonjer et al., $2005,2008)$. For each seismic source the intensity-frequency relation was calculated and a maximum possible earthquake was fixed. We assume a truncated exponential distribution as a seismicity model for each seismic source zone, defined by the parameters $a$ and $b$ of the intensity-frequency relation and by the maximum possible earthquake with intensity $I_{\max }$. The parameters $a$ and $b$ of each seismic source zone 
Table 1. Parameters of intensity-frequency relations and input parameters for seismic hazard calculation.

\begin{tabular}{|c|c|c|c|c|c|c|c|c|}
\hline Region & code & $\begin{array}{c}\text { start } \\
\text { year a) }\end{array}$ & $\begin{array}{c}\text { time } \\
\text { interval }\end{array}$ & $\begin{array}{c}a \\
\text { value }\end{array}$ & $\begin{array}{c}b \\
\text { value }\end{array}$ & $\begin{array}{l}\text { depth } \\
\mathrm{km}\end{array}$ & $\begin{array}{c}\text { Imax } \\
\text { observed }\end{array}$ & $\begin{array}{c}\text { Imax } \\
\text { possible }\end{array}$ \\
\hline Anatolian Fault ${ }^{\mathrm{b})}$ & $\mathrm{AF}$ & 1860 & 131 & 3.5535 & -0.2944 & 15 & 10.0 & 10.5 \\
\hline Banat $\mathrm{N}^{\mathrm{c})}$ & BA & 1843 & 148 & 4.1065 & -0.4325 & 10 & 8.5 & 8.5 \\
\hline Birlad $^{\mathrm{d})}$ & $\mathrm{BD}$ & 1896 & 95 & 3.7394 & -0.5923 & 25 & 6.5 & 7.0 \\
\hline Crisana Marmamures & $\mathrm{CM}$ & 1781 & 210 & 4.9340 & -0.5908 & 10 & 8.0 & 8.5 \\
\hline Dinnaridi 1 & D1 & 1860 & 131 & 4.5376 & -0.4827 & 10 & 9.0 & 9.0 \\
\hline Dinnaridi $2^{\mathrm{e})}$ & D2 & 1860 & 131 & 4.8515 & -0.4209 & 15 & 9.5 & 9.5 \\
\hline Banat $\left.S^{c}\right)$ & DA & 1864 & 127 & 3.6362 & -0.4325 & 12 & 8.0 & 8.5 \\
\hline Fagaras Campulung & $\mathrm{FC}$ & 1517 & 474 & 3.0427 & -0.2679 & 20 & 8.5 & 9.0 \\
\hline Greece 1 & G1 & 1860 & 131 & 4.9603 & -0.4472 & 20 & 10.0 & 10.5 \\
\hline Greece 2 & $\mathrm{G} 2$ & 1860 & 131 & 3.7025 & -0.3500 & 15 & 10.0 & 10.5 \\
\hline Greece 3 & G3 & 1860 & 131 & 2.2467 & -0.2635 & 15 & 8.5 & 9.0 \\
\hline Gorna Orjahovitza $^{\text {f) }}$ & GO & 1860 & 131 & 3.7210 & -0.4320 & 10 & 9.5 & 9.5 \\
\hline Hungary Central & $\mathrm{H} 2$ & 1753 & 238 & 4.2196 & -0.4430 & 10 & 8.5 & 9.0 \\
\hline Hungary + Serbia $^{g}$ ) & HS & 1738 & 253 & 3.9957 & -0.4609 & 8 & 8.5 & 9.0 \\
\hline Kresnah) & $\mathrm{KR}$ & 1860 & 131 & 3.4021 & -0.3536 & 15 & 10.0 & 10.5 \\
\hline Marica $1^{\mathrm{k})}$ & M1 & 1860 & 131 & 2.8648 & -0.3366 & 10 & 7.0 & 7.5 \\
\hline Marica $2^{\mathrm{k})}$ & M2 & 1860 & 131 & 3.5383 & -0.3366 & 10 & 9.5 & 10.0 \\
\hline NE Bulgaria $1^{\text {i) }}$ & N1 & 1860 & 131 & 2.5390 & -0.3228 & 20 & 8.5 & 9.0 \\
\hline NE Bulgaria $2^{\text {i) }}$ & $\mathrm{N} 2$ & 1860 & 131 & 2.8401 & -0.3228 & 15 & 7.5 & 8.0 \\
\hline Predobroudja ${ }^{d}$ ) & PD & 1832 & 159 & 4.1374 & -0.5923 & 20 & 7.5 & 7.5 \\
\hline Serbia E & $\mathrm{S} 1$ & 1886 & 105 & 4.6382 & -0.4761 & 10 & 9.0 & 9.5 \\
\hline Serbia W & S3 & 1894 & 97 & 6.0814 & -0.8025 & 10 & 7.5 & 8.0 \\
\hline Sofia & SF & 1800 & 191 & 4.5656 & -0.5003 & 10 & 9.0 & 9.5 \\
\hline Shabla ${ }^{\mathrm{j})}$ & SH & 1860 & 131 & 3.7496 & -0.4638 & 20 & 10.0 & 10.5 \\
\hline Southern Bulgaria $2^{\mathrm{k})}$ & SL & 1860 & 131 & 3.9272 & -0.5380 & 10 & 7.5 & 8.0 \\
\hline Southern Bulgaria $1^{\mathrm{k})}$ & SU & 1860 & 131 & 4.1825 & -0.5380 & 10 & 8.0 & 8.5 \\
\hline South-West Bulgarial) & SW & 1860 & 131 & 4.1573 & -0.4686 & 15 & 10.0 & 10.0 \\
\hline Turkey & $\mathrm{T} 1$ & 1860 & 131 & 3.5312 & -0.3164 & 15 & 10.0 & 10.5 \\
\hline Vrancea, normal depth & VN & 1802 & 189 & 3.0232 & -0.3846 & 30 & 8.0 & 8.5 \\
\hline Vrancea, intermediate & $\mathrm{Vi}$ & 1701 & 290 & 4.2821 & -0.4150 & 120 & 9.0 & 9.5 \\
\hline Background & BG & 1817 & 174 & 3.9493 & -0.4530 & 10 & 8.5 & 8.5 \\
\hline
\end{tabular}

a) End year for all regions is 1990; usually, only events with intensities of 5.5 or more are considered.

b) The regression curve in the cumulative intensity-frequency relation for region AF is calculated without the single event with intensity 10.0 MSK for statistical reasons; the next lower class IX contains 9 events.

c) For the two regions BA and DA, the events are added and a common intensity-frequency statistic is done, resulting in a common b-value. The a-value is computed using the cumulative number of events with intensity class 7.0 MSK and more for region BA; and with intensity class 6.0 MSK and more for region DA.

d) For the two regions BD and PD, the events are added and a common intensity-frequency statistic is done, resulting in a common b-value. The a-value for each region is computed, using the cumulative number of events with intensity class 5.0 and greater.

e) The regression curve in the cumulative intensity-frequency relation for region D2 is calculated without the single event with intensity 10.0 MSK, for statistical reasons; the next lower class IX contains 17 events.

f) The regression curve in the cumulative intensity-frequency relation for region GO is calculated without the single event with intensity 10.0 MSK, for statistical reasons; the next strongest event has intensity 8.0 MSK.

g) Only events with intensities class 7.0 or more are considered.

h) The regression curve in the cumulative intensity-frequency relation for region KR is calculated without the two events with intensity 10.0 MSK, for statistical reasons; the next strongest event has intensity 8.0 MSK.

i) For the two regions $\mathrm{N} 1$ and N2, the events are added and a common intensity-frequency statistic is done, resulting in a common b-value. However, the a-value for each region is computed separately, using the cumulative number of events with intensity class 6.0 and greater.

j) The regression curve in the cumulative intensity-frequency relation for region SH is calculated without the single event with intensity 10.0 MSK, for statistical reasons; then the strongest event has an intensity of 8.0 MSK. The statistic was done for a bigger area (thin lines in Fig. 1) because of suspected mislocated events; the used size of the source region SH is shown by thick lines.

k) For the regions M1 and M2 as well as for the regions SL and SU, the events are added and a common intensity-frequency statistic is done, resulting in a common b-value for each pair. The a-value for each region is computed, using the cumulative number of events with intensity class 6.0 and greater.

1) The regression curve in the cumulative intensity-frequency relation for region SW is calculated without the single event with intensity 10.0 MSK, for statistical reasons; the next strongest event has intensity 8.0 MSK. 


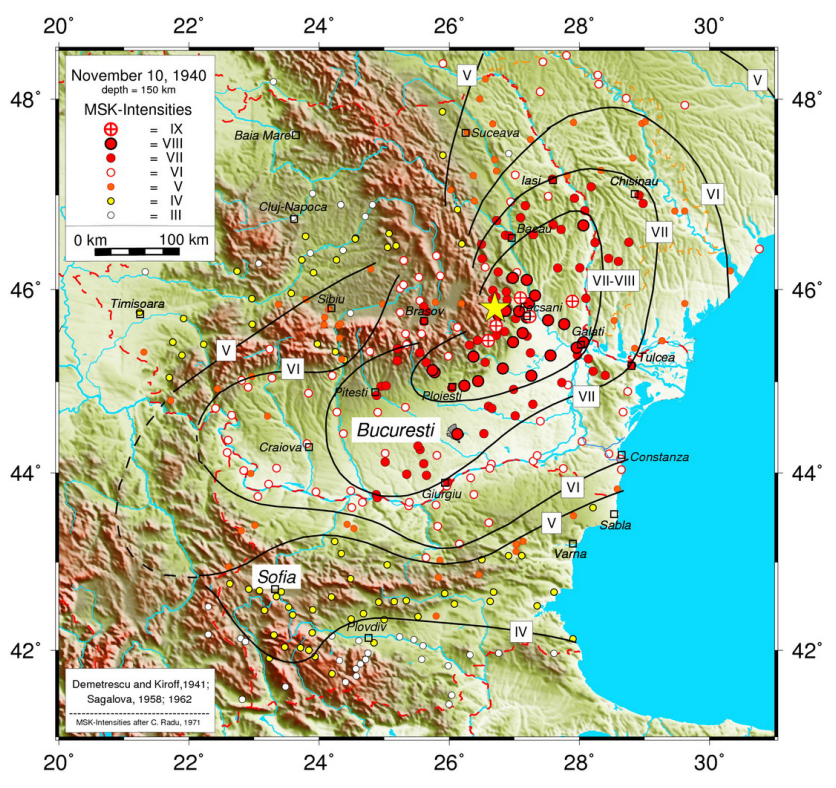

Fig. 2. Macroseismic map (in MSK intensity) of the 1940 Vrancea earthquake (10 November 1940) with epicentral intensity $I_{\text {epic }}=I X$ MSK, moment magnitude $M_{w}=7.7$ and focal depth $h=150 \mathrm{~km}$. The intensity values are from Demetrescu (1941) and are reduced according to Radu et al. (1990).

are calculated by the least square method using the following equation:

$\log N(I)=a+b I_{\text {epic }}$

where $N(I)$ is the cumulative number of earthquakes with intensity $I \geq I_{\text {epic }}$. Half intensity values were used, in contrast to the earlier papers (Ardeleanu et al., 2005, 2007; Simeonova et al., 2006) where the half intensities were rounded up to the next full number.

The beginning of the time period is chosen according to an assumed completeness of the catalogue for events greater than the lowest intensity values used in the statistics (Table 1).

Some of the seismic zones (as for example the seismic sources N1 and N2 in Northern Bulgaria, see Table 1) display low and dispersed seismicity. Since it is not possible to determine a reliable intensity-frequency relation for each of these sources separately, they are treated in a special way (see i) in Table 1) to calculate the intensity-frequency statistics.

All model parameters for PSHA are summarized in Table 1 .

\section{Attenuation models}

\subsection{Shallow earthquakes}

We implemented into the program EQRISK the intensity attenuation function of Sponheuer (1960) which is based on

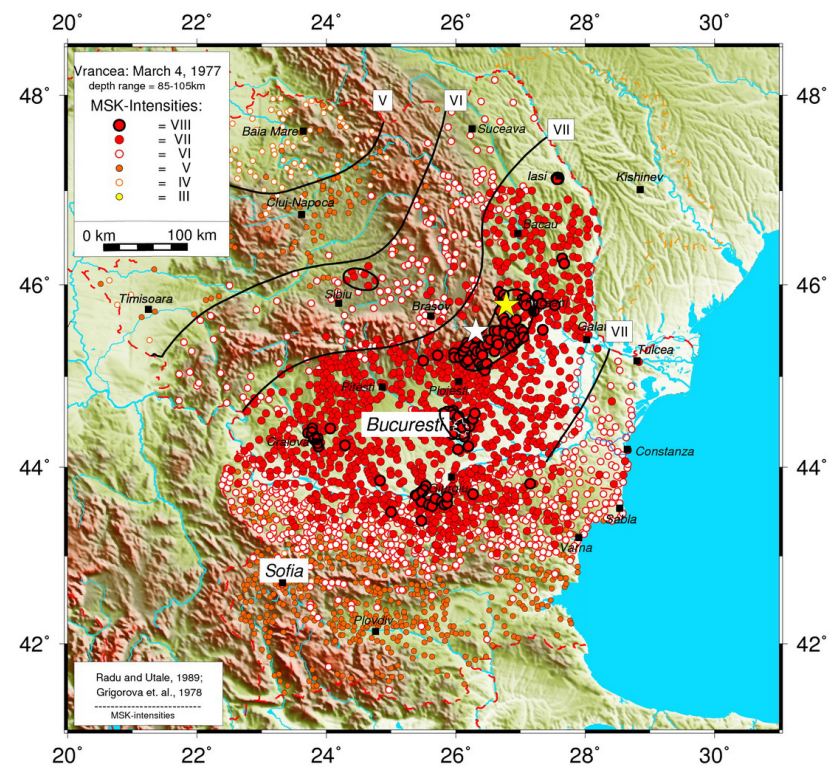

Fig. 3. Macroseismic map (in MSK intensity) of the 1977 Vrancea earthquake (4 March 1977) with epicentral intensity $I_{\text {epic }}=$ VIII MSK, moment magnitude $M_{w}=7.5$ and focal depth $h=94 \mathrm{~km}$. Intensity values are from Radu and Utale (1989) for the Romanian territory. The Bulgaria data are a refined version of Grigerova et al. (1978). The yellow star represents the rupture initiation (epicenter), the white star the rupture termination (stopping) according to Müller et al. (1978).

Kövesligethy (1907). The attenuation is given by the following equation:

$I_{\text {site }}=I_{\text {epic }}-3 \log (r / h)-1.3 a(r-h)$

$I_{\text {epic }}$ is the epicentral intensity, $I_{\text {site }}$ the intensity at a site at hypocentral distance $r(\mathrm{~km}) ; h$ is the focal depth $(\mathrm{km})$, and $a$ the absorption coefficient. Here we considered $a=0.002 \mathrm{~km}^{-1}$.

For a hazard curve at a site EQRISK cuts all source regions into finite ring segments with their assigned statistical parameters. Then the site intensities caused by earthquakes of each segment are calculated assuming a standard deviation of half an intensity for the attenuation function. The sum of the contributions of all regions finally leads to the annual probability of exceedance at each grid point of the hazard map. These calculations are done for all points between $39^{\circ} \mathrm{N}$ to $49^{\circ} \mathrm{N}$ and $19.5^{\circ} \mathrm{E}$ to $30.0^{\circ} \mathrm{E}$ every $0.1^{\circ}$ in latitude and $0.2^{\circ}$ in longitude. Figure 5 shows the seismic hazard for Romania and Bulgaria due to the shallow earthquakes for a recurrence period of 475 years.

\subsubsection{Vrancea intermediate depth earthquakes}

The macroseismic field of intermediate depth earthquakes of the Vrancea zone Vi (Romania) is very irregular as shown in Figs. 2 and 3 for the destroying earthquakes of 1940 and 


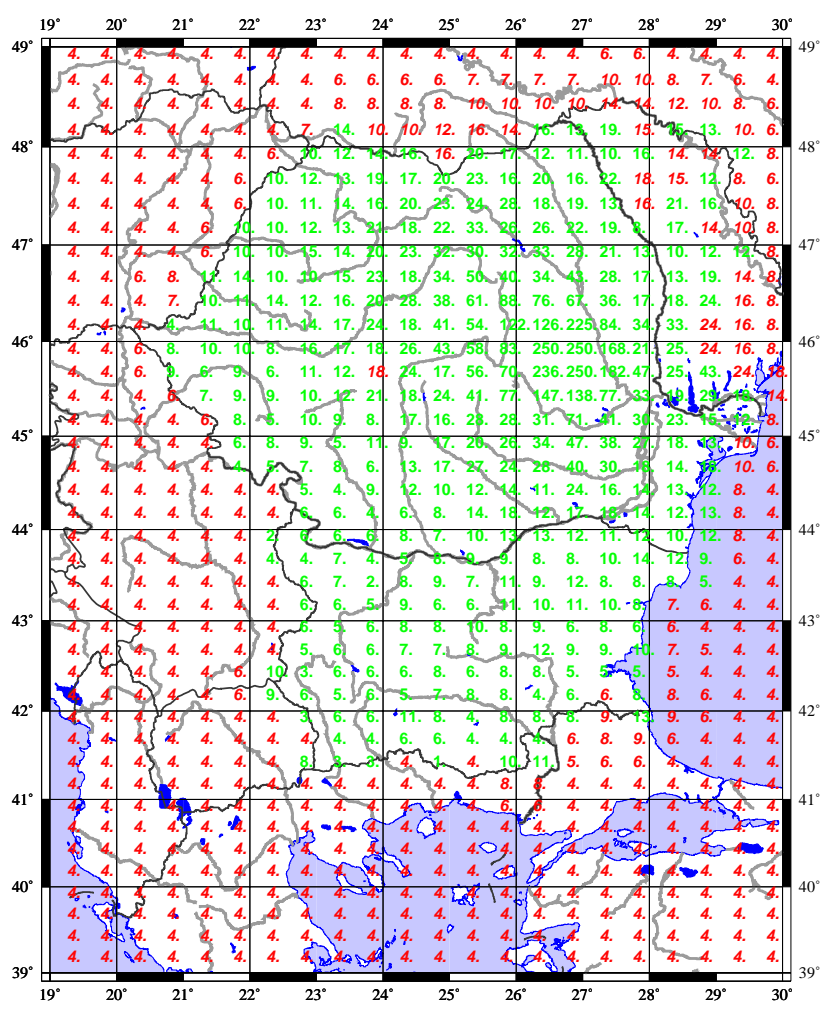

Fig. 4. The distribution of $\Omega$. The $\Omega$ pattern mimics the trends of the general strong decay of the seismic intensity pattern of the big intermediate depth Vrancea earthquakes in NW-SE direction. The green typed $\Omega$ values are based on macroseismic observations. Because no detailed digital macroseismic data outside Bulgaria and Romania were available, the $\Omega$ values there were fixed by us (red numbers). Therefore the seismic hazard values outside Bulgaria and Romania in Fig. 6-10 may be erroneous.

1977. These figures demonstrate as well as the macroseismic field of the strong earthquake in 1986 (Radu et al., 1987) that the attenuation in the North-West and South-East directions is substantially higher than in the North-East and South-West directions. To account for the apparent azimuthal dependency of the Vrancea intermediate depth earthquake attenuation, different approaches were made and several attenuation relationships were developed (e.g. Mârza and Pântea, 1995; Lungu et al., 1997; Moldovan et al., 2000; Radulian et al., 2006). These investigations do not consider the influence of the local site responses, but rather average those out. We therefore took a different approach.

As the attenuation relation (Eq. 2) does not consider azimuthal differences in attenuation, a new empirical approach is chosen to take the directionality of attenuation and local site effects into account. We introduced a factor $\Omega$ (Ardeleanu et al., 2005) into Eq. (2). This new attenuation model for Vrancea intermediate depth earthquakes is given by the relation:

$I_{\text {site }}=I_{\text {epic }}-3 \log (r / h)-1.3 \alpha * \Omega(r-h)$

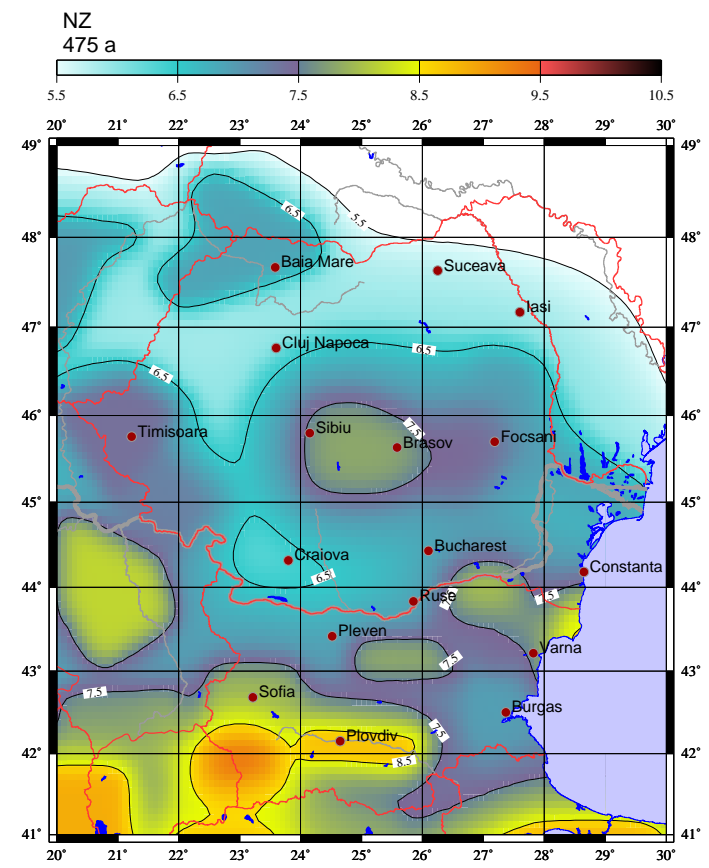

Fig. 5. Seismic hazard from source zones of normal depth for a recurrence period of 475 years; colours represent the intensities in MSK-1964 scale.

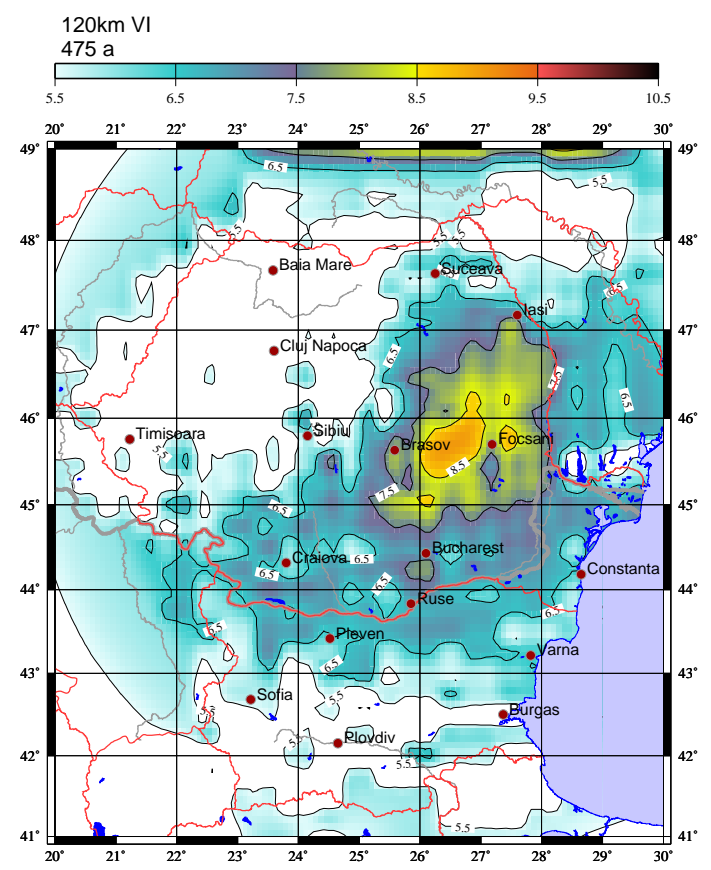

Fig. 6. Seismic hazard from Vrancea earthquakes of intermediate depth for a recurrence period of 475 years; colours represent intensities in MSK-1964 scale. The hazard values outside Romania and Bulgaria may be erroneous (see remarks to Fig. 4). 


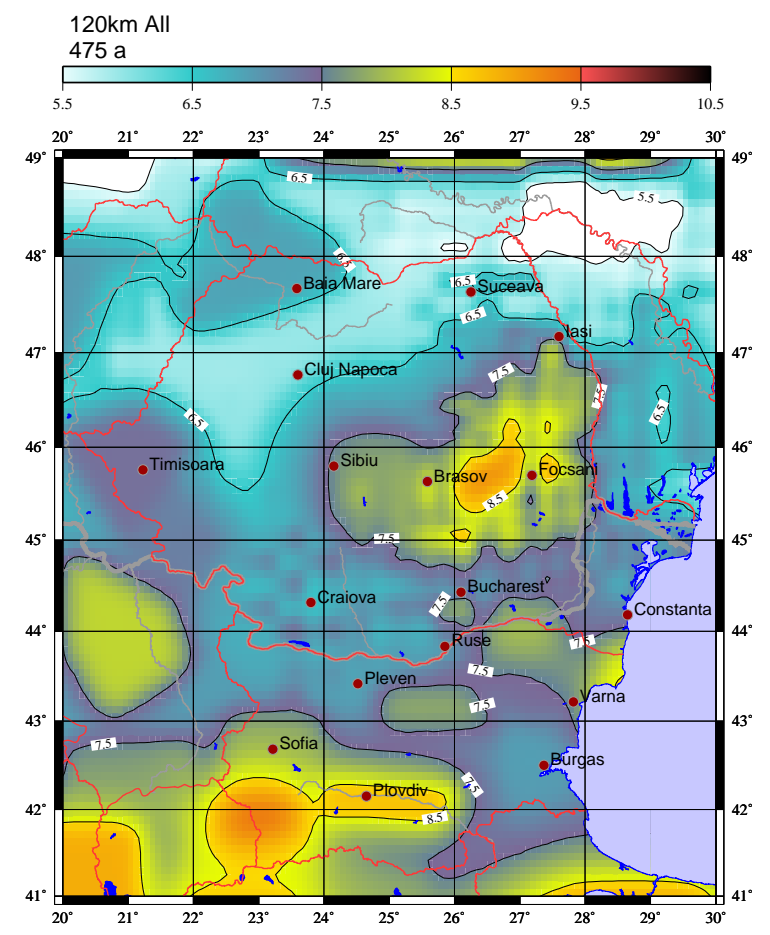

Fig. 7. Seismic hazard from all source zones (zones of crustal events and Vrancea events of intermediate depth) for a recurrence period of 475 years; colours represent intensities in MSK-1964 scale. The hazard values outside Romania and Bulgaria may be erroneous (see remarks to Fig. 4).

For the determination of $\Omega$ the following digitized macroseismic data were used:

- Vrancea 10 November 1940 ( $I_{\text {epic }}=$ IX MSK, moment magnitude $M_{w}=7.7, h=150 \mathrm{~km}$, Fig. 2): The macroseismic map of Demetrescu (1941) with the intensity distribution in Romania and Bulgaria was digitized and georeferenced by the Institute for Photogrammetry and Remote Sensing (IPRS) of Karlsruhe University. The data of the Republic of Moldova and Ukraine were taken from the map of Sagalova (for details see Bonjer et al., 2008). According to Radu et al. (1990), Radu and Sandi (1992) as well as Atanasiu and Kräutner (1941) reduced intensity values of the original data of Demetrescu and Sagalova were used to meet the MSK-scale and thus enabling comparison with the 1977 and 1986 Vrancea earthquake intensities.

- Vrancea 4 March 1977 ( $I_{\text {epic }}=$ VIII MSK, $M_{w}=7.5$, $h=94 \mathrm{~km}$, Fig. 3), and 30 August 1986 ( $I_{\text {epic }}=$ VIII MSK, $\left.M_{w}=7.2, h=130 \mathrm{~km}\right)$. Because no listings of the intensities of the Romanian territory were available, the macroseismic maps of Radu and Utale (1989) and Radu et al. (1987) with a scale of 1:1000000 were digitized and geo-referenced as well by the IPRS of Karlsruhe University. For the 1977 intensities of the

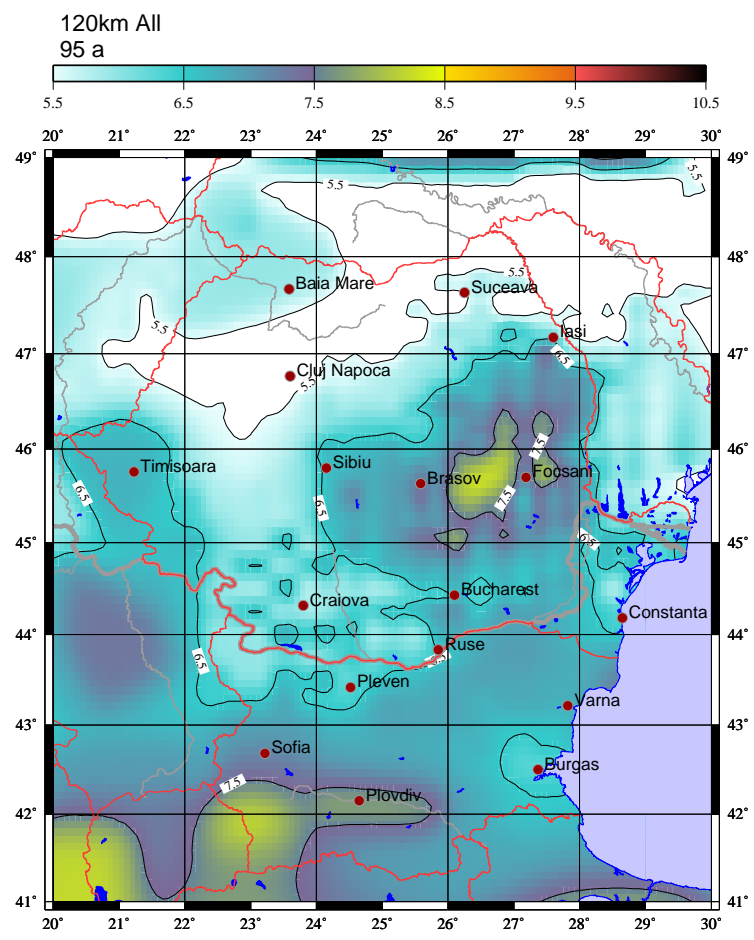

Fig. 8. Seismic hazard from all source zones (zones of crustal events and Vrancea events of intermediate depth) for a recurrence period of 95 years; colours represent intensities in MSK-1964 scale. The hazard values outside Romania and Bulgaria may be erroneous (see remarks to Fig. 4).

Bulgarian territory an upgraded version (Glavcheva, 1983) of the Grigerova et al. (1978) intensities was used. R. Glavcheva (personal communication) also provided the listing of the Bulgarian intensity data for the Vrancea 1986 event.

In Ardeleanu et al. (2005) the macroseismic data of the 30 May 1990 event were used instead of those of the 1940 event, as we do here. The reason for this exchange is that in the 1990 event two shocks with comparable strength occurred within $14 \mathrm{~h}$. So, the macroseismic effects of both events may be superimposed and therefore inseparable.

$\Omega$ was calculated for each observation point fixing $\alpha=0.001 \mathrm{~km}^{-1}$. Strong local variations of $\Omega$ were avoided by calculating mean values inside grid cells of 0.5 degree in longitude and 0.25 degree in latitude, separately for each event. From these mean grid values the median is taken. Intensities for rectangles without observations were 2-D-interpolated, respectively extrapolated. Figure 4 shows the resulting $\Omega$ field. The contribution of the Vrancea intermediate depth source zone to each grid point was computed with the corresponding representative $\Omega$ of this point.

Using the assigned $\Omega$ value for each point of computation, the seismic hazard of the Vrancea intermediate depth zone (Vi) is calculated in the same way as for the crustal zones. 


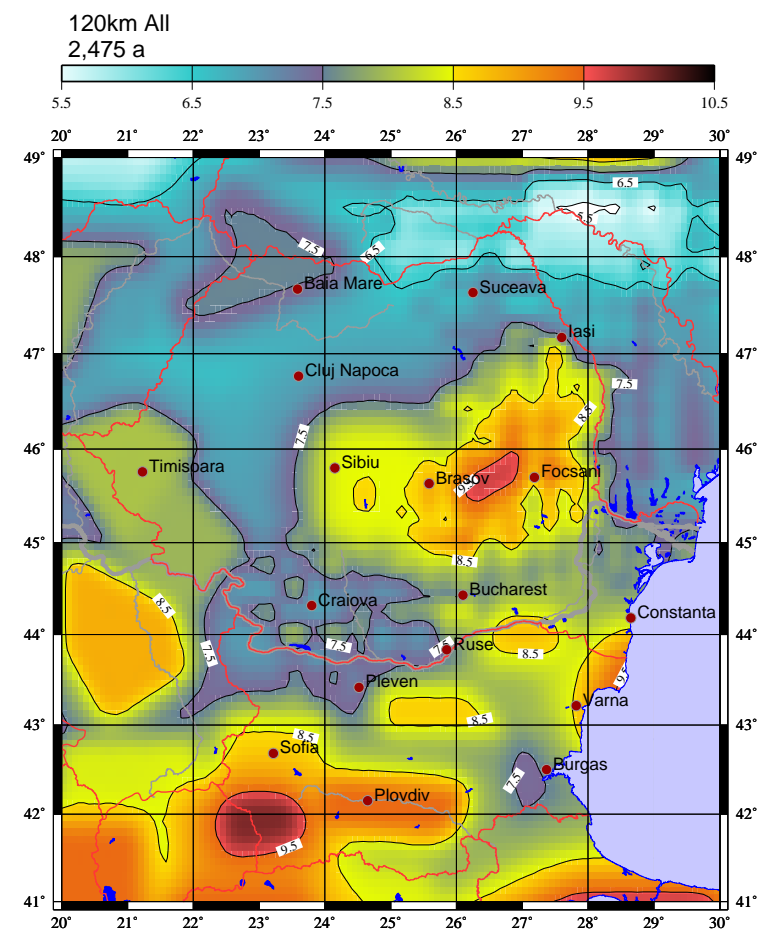

Fig. 9. Seismic hazard from all source zones (zones of crustal events and Vrancea events of intermediate depth) for a recurrence period of 2475 years; colours represent intensities in MSK-1964 scale. The hazard values outside Romania and Bulgaria may be erroneous (see remarks to Fig. 4).

A seismogenic depth of $120 \mathrm{~km}$ is assumed for the Vi source zone. Figure 6 shows as an example the seismic hazard from Vrancea intermediate depth earthquakes for the considered region for a recurrence period of 475 years.

\section{Results}

The final seismic hazard map for a recurrence period of 475 years in Fig. 7 is compiled by adding the expected value of the annual frequency of a certain intensity for normal depth source zones (Fig. 5) and for the Vrancea intermediate depth zone (Fig. 6) for every grid point before the common probability of exceedance of the final map is computed. The influence of the Vrancea intermediate depth zone on the seismic hazard is predominant for Romania, for Bulgaria it is important only for its northernmost part.

The separate computation and the separate compilation of the maps of the seismic hazard for the crustal and for the intermediate Vrancea earthquakes are not only an interesting feature for discriminating the sources and their contribution to the seismic hazard of a particular site. The separate computation is especially necessary for the creation of site specific response spectra in order to account for the different spectral content: the ground acceleration of the intermediate

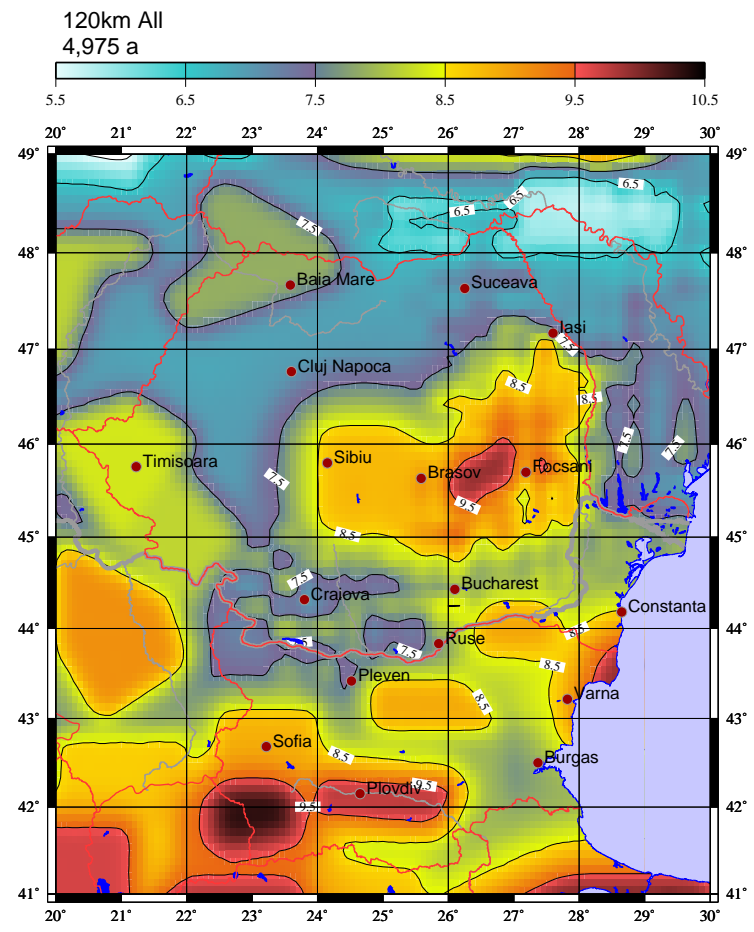

Fig. 10. Seismic hazard from all source zones (zones of crustal events and Vrancea events of intermediate depth) for a recurrence period of 4975 years; colours represent intensities in MSK-1964 scale. The hazard values outside Romania and Bulgaria may be erroneous (see remarks to Fig. 4).

earthquakes reaches the maximum values in the frequency band of $0.5-3 \mathrm{~Hz}$ (Lungu et al., 1999), whereas the crustal earthquakes have their acceleration maxima in a higher frequency band.

The building code EC 8 recommends a recurrence period of 475 years (probability of exceedance of $10 \%$ in 50 years) for the design earthquake (Fig. 7). In order to limit the damage of buildings and financial loss in case of weaker earthquakes with higher frequency of occurrence, a second hazard level in EC8 is recommended, corresponding to a recurrence period of 95 years (probability of exceedance of $10 \%$ in 10 years). The hazard map for both territories - Bulgaria and Romania - is presented in Fig. 8.

Special structures like large dams or high risk facilities are beyond the scope of EC 8, as they require higher safety standards. This would imply longer recurrence periods. In order to give decision makers a first information for regional planning we present in Figs. 9 and 10 the seismic hazard for a recurrence period of 2475 years (2\% in 50 years) and 4975 years (1\% in 50 years), respectively. These maps of course can not replace site specific expertises.

In comparison to former calculations in Ardeleanu et al. (2007) here the new hazard maps show reduced values in many parts. This is due to the following reasons: the statistics with classes in steps of half intensities (in former 
calculations half intensities have been counted to the next higher full intensity), enlarging the $\Omega$ field to the Bulgarian territory because of new available digitized macroseismic data from Vrancea intermediate depth earthquakes (in former calculations the $\Omega$ values for Bulgaria were assumed conservatively), and the downsizing of the Vrancea intermediate depth seismic source zone based on precise hypocenter localization. This in all results in more realistic seismic hazard maps.

Acknowledgements. The macroseismic map of Demetrescu (1941) was made available by Traian Moldoveanu, GEOTEC Consultant Bucharest. We thank W. Weisbrich, Institute of Photogrammetry and Remote Sensing, Karlsruhe University for digitizing and georeferencing this map as well as the maps of Radu and co-workers of the 1977 and 1986 Vrancea earthquakes. The digital file of the 1977 and 1986 Vrancea macroseismic data for Bulgaria was made available by I. Aleksandrova and B. Babachkova of the Bulgarian Academy of Sciences. One of the authors (K.-P. B.) enjoyed the discussion with R. Glavcheva, Bulgarian Academy of Sciences, and thanks for the generous sharing of her profound knowledge of the macroseismic scales used in Bulgaria and Romania for the determination of the intensities of the Vrancea 10 November 1940 earthquake. We are very grateful to Dieter Mayer-Rosa, Zurich, and Anton Zaicenco, Chisinau, for their constructive comments and important suggestions, which helped to improve the manuscript.

Edited by: M. Contadakis

Reviewed by: D. Mayer-Rosa and A. Zaicenco

\section{References}

Ardeleanu, L., Leydecker, G., Bonjer, K.-P., Busche, H., Kaiser, D., and Schmitt, T.: Probabilistic seismic hazard map for Romania as a basis for a new building code, Nat. Hazards Earth Syst. Sci., 5, 679-684, 2005,

http://www.nat-hazards-earth-syst-sci.net/5/679/2005/.

Ardeleanu, L., Leydecker, G., Bonjer, K.-P., Schmitt, T., Busche, H., Kaiser, D., Simeonova, S., and Solakov, D.: Probabilistic seismic hazard maps in terms of intensities for Romania and Bulgaria - Proceedings of International Symposium on Strong Vrancea Earthquakes and Risk Mitigation, 4-6 Oct 2007, Bucharest/Romania, published by Matrix Rom, Bucharest, 128131, ISBN 978-973-755-247-1, 2007.

Atanasiu, I. and Kräutner, T.: Das Erdbeben vom 10. November 1940 in Rumänien (The earthquake from Nov. 10, 1940 in Romania), Veröffentlichungen der Reichsanstalt für Erdbebenforschung in Jena, Berlin, Heft 40, 7-30, 1941.

Bonjer, K.-P., Ionescu, C., Sokolov, V., Radulian, M., Grecu, B., Popa, M., and Popescu, E.: Source parameters and ground motion pattern of the October 27, 2004 intermediate depth Vrancea earthquake, EGU General Assembly 2005, Vienna, Geophys. Res. Abstr., 7, EGU05-A-07538, 2005.

Bonjer, K.-P., Ionesccu, C., Sokolov, V., Radulian, M., Grecu, B., Popa, M., and Popescu, E.: Ground motion patterns of intermediate-depth Vrancea earthquakes: the October 27, 2004 event, in: Harmonization of Seismic Hazard in Vrancea Zone, Springer, NATO Science for Peace and Security Series-C: Envi- ronmental Security, edited by: Zaicenco, A., Craifaleanu, I., and Paskaleva, I., 47-62, 2008.

Christoskov, L., Grigorova, E., Sokerova, D., and Rijikova, S.: New catalogue of the earthquakes in Bulgaria for the period V century BC to XIX century (1899), Archives of the Geophysical. Inst., Bulgarian Acad. Sci., (unpublished), 1979.

Cornell, C.: Engineering Seismic Risk Analysis, BSSA, 5, 15831606, 1968.

Demetrescu, G.: Détermination provisoire de l'épicentre du tremblement de terre de Roumanie du 10 Novembre 1940, Observatoire de Bucuresti, Station sismique, 10 pp., 1941.

Glavcheva, R.: Impacts on PR Bulgaria, 178-187, in: Vrancea earthquake in 1977, Its after-effects in the People's Republic of Bulgaria, edited by: Brankov, G., Earthquake Engineering National Committee, Bulg. Acad. Sci., Sofia, 428 pp., 1983.

Grigorova, E., Glavtcheva, R., and Sokerova, D.: The earthquake on March 4, 1977 - Some results of seismic observations in Bulgaria, in: Proceedings of the Symposium on the Analysis of Seismicity and on Seismic Risk, Liblice, October 1977, 109-113, 1978.

Grigorova, E., Sokerova, D., Christoskov, L., and Rijikov, S.: Catalogue of the earthquakes in Bulgaria for the period 1900-1977, Archives of the Geophysical. Inst., Bulg. Acad. Sci. (unpublished), 1979.

Kiroff, K.: Earthquakes in Bulgaria, Report on felt earthquakes during years 1931-1940, Centr. Met. Inst., Sofia, 32-41, 112 pp., 1941 (in Bulgarian).

Kövesligethy von, R.: Seismischer Stärkegrad und Intensität der Beben (degree of seismic strength and intensity of earthquakes), Gerlands Beiträge zur Geophysik, Band VIII, Leipzig, 1907.

Lungu, D., Zaicenco, A., Cornea, T., and van Gelder, P.: Seismic hazard: recurrence and attenuation of subcrustal $(60-170 \mathrm{~km})$ earthquakes, Structural Safety and Reliability, 7, 1525-1532, 1997.

Lungu, D., Cornea, T., and Nedelcu, C.: Hazard assessment and dependent response for Vrancea earthquakes, in: Vrancea earthquakes: tectonics, hazard and risk mitigation, edited by: Wenzel, F., Lungu, D., and Novak, O., Kluwer Academic Publishers, Dordrecht, Netherlands, 251-267, 1999.

Mârza, V. I. and Pântea, A. I.: Probabilistic estimation of seismic intensity attenuation for Vrancea (Romania) subcrustal sources, in: Proc. XXIV Gen. Ass. of the E.S.C., 19-24 September 1994, Athens, Greece, v. III, 1752-1761, 1995.

McGuire, R.: FORTRAN Computer Program for Seismic Risk Calculations, U.S. Geol. Survey. Open-File Rep. 76-67, p. 90, 1976.

Moldovan, I.-A., Enescu, B .D., and Ionescu, C.: Predicting Peak Ground Horizontal Acceleration for Vrancea large Earthquakes using Attenuation relations for moderate shocks, Rom. Journ. Phys., 45, 9-10, 785-800, 2000.

Müller, G., Bonjer, K.-P., Stöckl, H., and Enescu, D.: The Romanian earthquake of March 4, 1977, I. Rupture process inferred from fault-plane solution and multiple event analysis, J. Geophys., 44, 203-208, 1978.

Oncescu, M.-C., Marza, V. I., Rizescu, M., and Popa, M.: The Romanian earthquake catalogue between 984-1997, in: Vrancea earthquakes: tectonics, hazard and risk mitigation, edited by: Wenzel, F., Lungu, D., and Novak, O., Kluwer Academic Publishers, Dordrecht, 43-47, 1999.

Papazachos, B., Cominakis, P., Karakaisis, G., Karakostas, B., Pa- 
paioannou, C., Papazachos, C., and Skordilis, E.: A catalogue of earthquakes in Greece and surrounding area for the period 550 BC-1999, Publ. Geophys. Lab. Univ. of Thessaloniki (computer file), 2000.

Papazachos, B., Cominakis, P., Skordilis, E., Karakaisis, G., and Papazachos, C.: A catalogue of earthquakes in the Mediterranean and surrounding area for the period 1901-2004, Publ. Geophys. Lab. Univ. of Thessaloniki (computer file), 2005.

Radu, C., Polonic, G., and Apopei, I.: Macroseismic map of March 4, 1977 Vrancea Earthquake (in Romanian), Report CSEN, Bucharest, 1977.

Radu, C., Utale, A., and Winter, V.: The August 30, 1986 Vrancea earthquake, Seismic intensity distribution, National Institute for Earth Physics report, II, A-3. 1987.

Radu, C. and Utale, A.: A new version of the March 4, 1977 Vrancea earthquake (in Romanian), Report CEPS, theme 30.86.3/1989, II, A4, 31-32, Bucharest, 1989.

Radu, C., Radulescu, D., and Sandi, H.: Some data and considerations on recent strong earthquakes of Romania, Cahier Technique, 3, AFPS, Paris, 19-31, 1990.

Radu, C. and Sandi, H: Recent Strong Earthquakes in Romania and their Impact on Earthquake Resistant Design Regulations, Manuscript, 22 pp., 1992.

Radulian, M., Panza, G. F., Popa M., and Grecu, B.: Seismic wave attenuation for Vrancea events revisited, J. Earthquake Eng., 10, 411-427, 2006.
Report GPh. I.: New seismic zoning of Bulgaria, Part I, Bulgarian Academy of Sciences, Geophysical Institute, Sofia, 205 pp., 2007 (in Bulgarian).

Simeonova, S. D., Solakov, D. E., Leydecker, G., Busche, H., Schmitt, T., and Kaiser, D.: Probabilistic seismic hazard map for Bulgaria as a basis for a new building code, Nat. Hazards Earth Syst. Sci., 6, 881-887, 2006, http://www.nat-hazards-earth-syst-sci.net/6/881/2006/.

Shebalin, N. V., Leydecker, G., Mokrushina, N., Tatevossian, R., Erteleva, O., and Vassilev, V.: Earthquake Catalogue for Central and Southeastern Europe, European Commission, Report No. ETNU CT93-0087 (for catalogue download: http://www.bgr.de/ quakecat), Brussels, 1998.

Solakov, D. and Simeonova, S.: Bulgaria Catalogue of Earthquakes 1981-1990, Sofia Press, p. 40, 1993.

Sponheuer, W.: Methoden zur Herdtiefenbestimmung in der Makroseismik, (Methods for depths estimation in macroseismic), Freiberger Forschungs-Hefte C 88, Akademie Verlag Berlin, 117 pp., 1960.

Stepp, J.: An investigation of earthquake risk in the Puget Sound area by use of the type I distribution of large extremes, Ph.D. thesis, Pennsylvania Univ., 131 pp., 1971. 